Rabaska

Revue d'ethnologie de l'Amérique française

\title{
Le Patrimoine culturel immatériel
}

Volume 3, 2005

URI : https://id.erudit.org/iderudit/039437ar

DOI : https://doi.org/10.7202/039437ar

Aller au sommaire du numéro

Éditeur(s)

Société québécoise d'ethnologie

ISSN

1703-7433 (imprimé)

1916-7350 (numérique)

Découvrir la revue

Citer ce document

(2005). Le Patrimoine culturel immatériel. Rabaska, 3, 103-103.

https://doi.org/10.7202/039437ar

Ce document est protégé par la loi sur le droit d'auteur. L'utilisation des services d'Érudit (y compris la reproduction) est assujettie à sa politique d'utilisation que vous pouvez consulter en ligne.

https://apropos.erudit.org/fr/usagers/politique-dutilisation/
Cet article est diffusé et préservé par Érudit.

Érudit est un consortium interuniversitaire sans but lucratif composé de l'Université de Montréal, l'Université Laval et l'Université du Québec à Montréal. Il a pour mission la promotion et la valorisation de la recherche. https://www.erudit.org/fr/ 


\section{Place publique}

Points de vue

\section{Le Patrimoine culturel immatériel}

L'adoption par l'UNESCO de la déclaration d'Istanbul définissant le patrimoine culturel immatériel en septembre 2002 a marqué un temps fort pour le Québec qui avait entrepris une réflexion en vue de se doter d'une nouvelle politique culturelle ; le rapport Arpin s'en était fait l'écho en 2000 (Cf. Rabaska 1, pp. [113]-135). Par la suite, le Groupe de travail sur le patrimoine immatériel, réuni par le ministère de la Culture et des communications, a déposé son mémoire sur la question en octobre 2001. Le document officiel, que RABASKA a soumis à des experts spécialement investis dans ce champ d'activités, en est une «version revue et abrégée». Quatre d'entre eux livrent ici leur point de vue : $M^{\text {me }}$ Françoise Lempereur offre d'abord le regard d'un universitaire européen, tandis que M. Pierre Chartrand d'une part et $\mathrm{M}^{\text {mes }}$ Lisan Hubert et Danielle Martineau d'autre part exposent la perception de centres d'animation québécois sur ce dossier.

Bernard Genest et Camille Lapointe, Le Patrimoine culturel immatériel. Un capital social et économique, Québec, Gouvernement du Québec, Culture et Communications, 2004, 77 p. ISBN 2-550-42524-3.

\section{Définir le patrimoine culturel immatériel...} une gageure?

Françoise Lempereur

Unité de recherche en Médiation culturelle Département d'Information et Communication Université de Liège, Belgique

\section{Actualité et nécessité}

Lorsque, le 16 octobre 2003, la XXXII Conférence générale de l'UNESCO adopte la Convention internationale pour la sauvegarde du patrimoine culturel immatériel, le monde des traditions orales est déjà bien malade. 